\title{
PENERAPAN MODEL PEMBELAJARAN KOOPERATIF TIPENUMBER HEAD TOGETHER (NHT) DALAM MENINGKATKAN HASIL BELAJAR SISWAKELAS III-B PADA MATA PELAJARAN IPS DI SD NEGERI 064024 MEDAN SELAYANG TAHUN PEMBELAJARAN 2017/2018
}

\author{
OLEH: \\ KRISTINA SELLY BR BARUS \\ (PGSD FKIP UNIVERSITAS KATOLIK SANTO THOMAS SU)
}

\begin{abstract}
The problem in the research is the low learning result of Social Science (IPS) of natural and artificial environment in class III, one of the causal factor is the instructional model used by the teacher is less varied. The purpose of this study is to determine the implementation of learning and improvement of student learning outcomes by using cooperative learning model type Number Head Together (NHT). This research was conducted at State Elementary School 064024 Medan Selayang, with classroom action research. The subjects of the research are students of class III-B amounting to 25 students, while the object of research is to improve the learning result of Social Sciences (IPS) by using cooperative learning model type Head Head Together on Social Science subject. Data collection techniques used observations and tests. From the results of data analysis obtained the results of observation of the implementation of teacher activity learning in cycle I obtained the number of points 34 with a percentage of $68 \%$. Observation of student activity cycle I obtained the number of points 26 with a percentage of $52 \%$. The classical learning outcomes increased from $40.00 \%$ to $88.00 \%$ and the average value increased from 60.08 to 77.06 . From the results of the study can be concluded the implementation of learning both categorized and student learning outcomes increased after using cooperative learning model type Number Head Together(NHT) on subjects Social Sciences material Natural and artificial environment in class III-B SD Negeri 064024 Medan Selayang.
\end{abstract}

Keywords: Learning Outcomes, Cooperative Learning Model Type Head Together (NHT).

\section{PENDAHULUAN \\ Latar Belakang Masalah}

Pendidikan merupakan usaha sadar dan terencana untuk mewujudkan suasana belajar dan proses pembelajaran agar siswa secara aktif mengembangkan potensi dirinya. Keberhasilan suatu pendidikan sangat terkait dengan hasil belajar siswa.Hasil belajar merupakan indikator dari keberhasilan siswa dalam pembelajaran.Melihat begitu pentingnya pendidikan dalam meningkatkan sumber daya manusia, peningkatan mutu pendidikan merupakan hal yang wajib guna menjawab perubahan zaman maka untuk itu seseorang harus belajar.

Belajar merupakan suatu aktivitas mental yang berlangsung dalam interaksi aktif antara seseorang dengan lingkungan, dan menghasilkan perubahan-perubahan tingkah laku, pengetahuan, pemahaman, dan keterampilan.Dengan belajar diharapkan adanya perubahan positif dari dalam diri siswa sehingga mampu menyelesaikan masalah dalam hasil belajar yang telah dilakukan. 
Dalam pembelajaran di sekolah dasar (SD) ada beberapa mata pelajaran yang diterapkan.Salah satunya mata pelajaran Ilmu Pengetahuan Sosial (IPS).Mata pelajaran IPS sangat penting untuk mengajarkan siswa agar dapat berinteraksi baik dengan lingkungan masyarakat.Pembelajaran IPS merupakan pembelajaran yang sangat penting bagi siswa yang berkaitan langsung dengan interaksi siswa dengan lingkungannya yang beragam situasi dan kondisi. Pada dasarnya pembelajaran IPS bertujuan untuk mengembangkan kemampuan siswa menggunakan penalaran dalam mengambil keputusan dan berusaha membantu siswa dalam memecahkan permasalahan yang dihadapi sehingga akan menjadikannya semakin mengerti dan memahami lingkungan sosial masyarakat.

Didalam proses pembelajaran guru harus memiliki strategi atau upaya untuk menciptakan lingkungan kelas yang lebih baik sehingga siswa dapat belajar secara efektif dan efisien supaya tujuan pembelajaran dapat tercapai. Salah satu tindakannya guru harus memiliki berbagai strategi/model pembelajaran untuk meningkatkan keaktifan siswa saat pembelajaran berlangsung.

Namun, dalam kenyataannya masih banyak guru yang tidak menggunakan model pembelajaran.Sehingga hasil belajar siswa dalam pelajaran IPS tergolong rendah.Dari hasil observasi di SD Negeri 064024 Medan Selayang, dapat dilihat rendahnya hasil belajar siswa pada mata pelajaran IPS dengan pokok bahasan lingkungan alam dan buatan.

\begin{tabular}{|c|c|c|c|}
\hline $\begin{array}{c}\text { Kriteria Ketuntasan } \\
\text { Minimum IPS }\end{array}$ & Jumlah siswa & \multicolumn{2}{|c|}{ Jumlah Siswa } \\
\cline { 3 - 4 } & & Tuntas & Tidak Tuntas \\
\hline 65 & 33 & $\begin{array}{c}12 \\
(36 \%)\end{array}$ & $(64 \%)$ \\
\hline
\end{tabular}

Tabel 1.1 Nilai hasil ujian siswa mata pelajaran IPS

Dari tabel 1.1 diatas menunjukkan bahwa di kelas III-B pada mata pelajaran IPS, Dari 33 orang siswa, siswa yang mencapai KKMsebanyak 12 orang siswa atau (36\%), sedangkan yang tidak mencapai KKMsebanyak 21 orang siswa atau (64\%). Data ini menunjukkan hasil belajar siswa pada mata pelajaran IPS belum memenuhi kriteria ketuntasan klasikal.

Hal ini terlihat saat proses pembelajaran berlangsung proses pembelajaran masih didominasi oleh guru, masih banyak siswa yang bermain-main ketika guru menjelaskan materi pelajaran, model pembelajaran yang digunakan guru kurang menyenangkan,kondisi kelas yang kurang nyaman, belum pernah diterapkannya model pembelajaran Number Head Together dalam pembelajaran IPS, guru kurang menggunakan alat peraga yang mendukung proses pembelajaran. Hal ini disebabkan karena model yang digunakan guru kurang menyenangkan.Akibatnya siswa kurang tertarik mempelajari mata Pelajaran IPS.Masalah tersebut yang menyebabkan rendahnya hasil belajar siswa.Maka dari itu, guru harus dapat menciptakan suasana yang kondusif dan membuat pembelajaran menjadi efektif dan menyenangkan.

Untuk mengatasi permasalahan tersebut, maka perlu diupayakan pembaharuan model pembelajaran. Dalam hal ini, peneliti tertarik untuk melakukan penelitian menggunakan model pembelajaran kooperatif tipeNumber Head Together.Model pembelajaran kooperatif tipeNumber Head Together merupakan model pembelajaran dengan permainan bernomor, dimana siswa bekerja dalam kelomok kecil, mereka saling membantu dalam mengatasi berbagai persoalan atau masalah yang diberikan guru sehingga mereka saling mengerti dan memahami pelajaran tersebut. 
Berdasarkan uraian diatas bahwa masih banyak siswa yang kurang berminat dalam belajar.Oleh sebab itu, diperlukan adanya satu tindakan agar dapat meningkatkan hasil belajar siswa pada pembelajaran IPS, salah satu tindakan yang dianggap dapat meningkatkan hasil belajar siswa adalah dengan menggunakan model pembelajaran yang sesuai dengan materi yang akan diajarkan untuk menjawab permasalahan yang ada maka peneliti merasa perlu untuk meneliti tentang " PENERAPAN MODEL PEMBELAJARAAN KOOPERATIF TIPE NUMBER HEAD TOGETHER (NHT) DALAM MENINGKATKAN HASIL BELAJAR SISWA KELAS III-B PADA MATA PELAJARAN IPS DI SD NEGERI 064024 MEDAN SELAYANG TAHUN PEMBELAJARAN 2017/2018".

\section{IdentifikasiMasalah}

Berdasarkan latar belakang masalah yang diuraikan, terkait rendahnya hasil belajar IPS siswa maka masalah yang dapat diidentifikasi yaitu:

1. Rendahnya hasil belajar siswa pada mata pelajaran IPS.

2. Poses pembelajaran masih didominasi oleh guru.

3. Kondisi kelas yang kurang nyaman,

4. Belum pernah diterapkannya model pembelajaran kooperatif tipeNumber Head Together dalam pembelajaran IPS,

5. Guru kurang menggunakan alat peraga untuk mendukung proses pembelajaran,

\section{Batasan Masalah}

Berdasarkan identifikasi masalah di atas maka permasalahan dalam penelitian ini dibatasi/difokuskan pada:

1. Rendahnya hasil belajar siswa pada mata pelajaran IPS kelas III-B SD Negeri 064024 Medan Selayang Tahun Pembelajaran 2017/2018.

2. Belum pernah diterapkan model pembelajaran kooperatif tipeNumber Head Together dalam proses pembelajaran IPS pada pokok bahasanLingkungan alam dan buatan di kelas III-B SD Negeri 064024 Medan Selayang Tahun Pembelajaran 2017/2018.

\section{Rumusan Masalah}

Berdasarkan batasan masalah diatas, maka rumusan permasalahan penelitian ini sebagai berikut:

1. Bagaimana penerapan model pembelajaran Number Head Together (NHT) pada mata pelajaran IPS SD Negeri 064024 Medan Selayang Tahun Pembelajaran 2017/2018?

2. Apakah dengan menggunakan model pembelajaran Number Head Together (NHT) dalam pelaksanaan pembelajaran IPS dapat meningkatkan hasil belajar siswa kelas III-B SD Negeri 064024 Medan Selayang Tahun Pembelajaran $2017 / 2018 ?$

\section{Tujuan Penelitian}

Adapun tujuan dari penelitian ini adalah:

1. Untuk mengetahui tingkat kemampuan siswa dalam pembelajaran IPS dengan menggunakan model pembelajaran Number Head Together (NHT) pada siswa kelas III-B SD Negeri 064024 Medan Selayang Tahun Pembelajaran 2017/2018.

2. Untuk mengetahui peningkatan hasil belajar IPS pada materi Lingkungan Alam dan Buatan dengan menggunakan model pembelajaran Number Head Together untuk siswa kelas III-B SD Negeri 064024 Medan Selayang Tahun Pembelajaran 2017/2018.

\section{Manfaat Penelitian}

Hasil penelitian ini dihaapkan dapat memberikan manfaat sebagai berikut: 


\section{a. Bagi Siswa}

Meningkatkan kemampuan berpikir siswa agar lebih kritis, kreatif dan inovatif baik dalam kegiatan pembelajaran maupun dalam kegiatan sehari-hari dan untuk meningkatkan hasil belajar siswa pada pembelajaran IPS.

\section{b. Bagi guru}

Sebagai bahan masukan bagi guru untuk memilih model dan strategi pembelajaran yang dilakukan di kelas, mempermudah guru dalam mencapai tujuan pembelajaran dan menerapkan model pembelajaran kooperatif tipe Number HeadTogether (NHT) secara terarah dapat meningkatkan hasil belajar siswa.

\section{c. Bagi Sekolah}

Sebagai bahan masukan bagi kepala sekolah dalam meningkatkan ketrampilan guru dalam mengajar khususnya dengan menggunakan model pembelajaran kooperatif tipe Number Head Together (NHT) sehingga diperoleh hasil belajar yang lebih baik

\section{d. Bagi Peneliti}

Sebagai usaha untuk meningkatkan pengetahuan dan pengalaman peneliti sebagai calon pendidik dalam upaya meningkatkan hasil belajar siswa.

\section{METODOLOGI PENELITIAN \\ Metode Penelitian}

Jenis penelitian yang dilakukan dalam penelitianini adalah penelitian tindakan kelas(PTK).Menurut Arikunto,dkk (2016:4) bahwa "PTK adalah penelitian yang memaparkan terjadinya sebab-akibat dari perlakuan, sekaligus memaparkan apa saja yang terjadi ketika perlakuan diberikan, dan memaparkan seluruh proses sejak awal pemberian perlakuan sampai dengan dampak dari perlakuan yang diberikan kepada subjek tindakan". Dengan menggunakan model pembelajaran kooperatif tipe Number Head Together.Penelitian ini bertujuan untuk memperbaiki pelaksanaan pembelajaran dan meningkatkan hasil belajar siswa dengan menggunakan model pembelajaran kooperatif tipe Number Head Togetherpada mata pelajaran IPS materi Lingkungan alam dan buatan kelas III-B SD Negeri 064024 Medan Selayang.

\section{Tempat dan Waktu Penelitian}

\section{Tempat Penelitian}

Penelitian ini dilaksanakan di SD Negeri 064024 Medan Selayang. Penetapan kelas ini diambil berdasarkan hasil observasi terhadap kelas yang akan diteliti.Alasan peneliti memilih lokasi tersebut:

1. Sekolah tersebut belum pernah diadakan penelitian yang sama dengan judul penelitian ini.

2. Data yang diperlukan untuk menjawab masalah ini memungkinkan diperoleh di sekolah tersebut.

3. Peneliti menginginkan adanya peningkatan hasil belajar pada mata pelajaran IPS dimana selama ini hasil belajar siswa masih tergolong rendah.

\section{Waktu Penelitian}

Penelitian Tindakan Kelas (PTK) ini dilaksanakan dalam dua minggu atau dua kali pertemuan.Penelitian dilaksanakan pada semester ganjil tahun pembelajaran 2017/2018.

\section{Subjek dan Objek Penelitian}

Subjek dari penelitian ini adalah siswa kelas III-B SD Negeri 064024 Medan Selayang dengan jumlah siswa sebanyak 25siswa, dimana jumlah siswa laki-laki 13 siswa dan jumlah siswa perempuan sebanyak 12 siswa. 
Objek penelitian ini adalah pembelajaran IPS dengan menggunakan model pembelajarankooperatif tipeNumber Head Together untuk meningkatkan hasil belajar siswa kelas III-B SD Negeri 064024 Medan Selayang.

\section{Jenis dan Sumber Data}

\section{Jenis Data}

Jenis penelitian yang digunakan peneliti pada penelitian ini adalah jenis data kuantitatif dan Kualitatif.Data Kuantitatif pada penelitian ini berisi nilai hasil belajar siswa yang diperoleh melalui tes yang digunakan untuk mengukur kemampuan kognitif siswa. Nilai hasil belajar tersebut diperoleh dari hasil pretest yang diberikan sebelum melaksanakan tindakan pada siklus I, serta posttest yang diberikan pada akhir pembelajaran siklus I dan II. Data Kualitatif dalam penelitian ini berupa data hasil pelaksanaan pembelajaran pada saat berlangsungnya proses belajar mengajar. Data tersebut berupa hasil pengamatan aktivitas guru dan siswa yang diperoleh melalui lembar pengamatan.

\section{Sumber Data}

Sugyiono (2013:193) menyatakan, "Dilihat dari sumber datanya, maka pengumpulan data dapat menggunakan sumber primer, dan sumber sekunder". Sumber primer adalah sumber data yang langsung memberikan data kepada pengumpul data, dan sumber sekunder adalah sumber yang tidak langsung memberikan data kepada pengumpulan data, misalnya lewat orang lain atau lewat dokumen. Sumber yang dipakai peneliti dalam penelitian ini adalah sumber primer, yaitu:

1. Informasi atau narasumber, yaitu guru kelas III-B SD Negeri 064024 Medan Selayang.

2. Daftar nilai mata pelajaran Ilmu Pengetahuan Sosial siswa kelas III-B SD Negeri 064024 Medan Selayang.

3. Tempat berlangsungnya aktivitas pembelajaran Ilmu Pengetahuan Sosial yaitu di SD Negeri 064024.

\section{Teknik Pengumpulan Data}

Teknik pengumpulan data merupakan cara yang dapat digunakan oleh peneliti untuk mengumpulkan data. Teknik pengumpulan data yang digunakan oleh peneliti untuk menghitung hasil belajar siswa dalam penelitian ini adalah tes.Menurut Asep Jihad (2013:67), "Tes merupakan himpunan pertanyaan yang harus dijawab, harus ditanggapi, atau tugas yang harus dilaksanakan oleh orang yang dites. Tes digunakan untuk mengukur sejauh mana seseorang siswa telah menguasai pelajaran yang disampaikan terutama meliputi aspek pengetahuan dan keterampilan”.

Tes hasil belajar Ilmu Pengetahuan Sosial dalam penelitian ini adalah berupa tes pilihan berganda yang disusun berdasarkan kisi-kisi instrumen yang telah disusun. Tes pilihan berganda ini dilaksanakan setelah proses pembelajaran berakhir pada setiap siklus untuk memperoleh data tentang hasil belajar siswa pada materi pelajaran Ilmu Pengetahuan Sosial.

Sedangkan untuk mengukur aktivitas guru dan siswa peneliti menggunakan lembar observasi.Teknik observasi merupakan teknik pengumpulan data dengan melakukan pengamatan pada objek penelitian.Pada penelitian ini melibatkan peneliti dan guru sebagai observer. Proses observasi dilakukan dengan mengacu pada pedoman observasi yang telah disusun. Aktivitas guru dan siswa diamati untuk mendapatkan 
seberapa besar pengaruh proses pembelajaran Ilmu Pengetahun Sosial dengan menggunakan model pembelajaran Number Head Together dapat mempengaruhi aktivitas guru dan siswa dan apakah kegiatan yang dilakukan telah sesuai dengan yang direncanakan dalam RPP.

\section{Validitas Instrumen Soal}

Menurut Tampubolon (2013:31) mengemukakan ,'Instrumen yang digunakan dalam penelitian bertujuan untuk memperoleh data tentang kualitas pembelajaran, motivasi belajar siswa, dan hasil belajar pada mata pelajaran tertentu". Sugiyono (2013:363) mengatakan, "validitas merupakan derajat ketetapan antara data yang terjadi pada obyek penelitian dengan daya yang dapat dilaporkan oleh peneliti". Dengan demikian data yang valid adalah data yang tidak berbeda antara data yang dilaporkan oleh peneliti dengan data yang sesungguhnya terjadi pada obyek penelitian.

Dalam penentuan tingkat validitas butir soal validitas bandingan product moment correlations dengan mengkorelasikan antar skor yang didapat siswa pada suatu butir soal dengan skor total yang didapat. Dalam hal ini rumus yang digunakan untuk kevaliditasian sebagai berikut.

$$
r_{x y}=\frac{N \sum x y-\left(\sum x\right)\left(\sum y\right)}{\sqrt{\left(N \sum x\right)^{2}-\left(\sum x\right)^{2}\left(N \sum y^{2}-\left(\sum y\right)^{2}\right)}}
$$

Dimana:

$$
\begin{array}{ll}
r_{x y} & =\text { Koefisien korelasi antara } \mathrm{X} \text { dan } \mathrm{Y} \\
\mathrm{N} & =\text { banyak siswa persentase } \\
\mathrm{X} & =\text { nilai hasil uji coba } \\
\mathrm{Y} & =\text { rata-rata siswa }
\end{array}
$$

Setelah diketahui koefisien korelasi antaraX danY,selanjutnya adalah menginterprestasikan besarnya koefisien korelasi dengan menggunakan kriteria sebagai berikut:

$0,80 \leq r_{x y} \leq 1,00=$ Sangat tinggi

$0,60 \leq r_{x y} \leq 0,80=$ Tinggi

$0,40 \leq r_{x y} \leq 0,60=$ Cukup

$0,20 \leq r_{x y} \leq 0,40=$ Rendah

$r_{x y} \leq 0,20=$ Sangat rendah

Instrumen soal pada penelitian ini dapat dikatakan valid jika $r_{x y}>r_{\text {tabel }}$ pada uji validitas ini $r_{\text {tabel }}$ yang dipakai adalah sebesar 0,361 dengan taraf signifikan sebesar 5\% dengan jumlah $\mathrm{N}$ sebanyak 30 orang siswa. Berdasarkan data tersebut setelah peneliti melakukan uji instrumen kepada siswa dan diujikan kevaliditanya dengan menggunakan program SPSS maka diperoleh hasil data yang valid dan data yang tidak valid.

Berdasarkan hasil data yang diperoleh setelah dilakukan uji validitas instrumen soal kepada 30 orang siswa dengan jumlah butir soal sebanyak 40 soal. Soal yang dinyatakan valid berjumlah 20 butir soal dan soal yang tidak valid berjumlah 20 butir soal. Peneliti memakai 20 soal dalam penelitiannya dengan jumlah pretesdan postessiklus I sebanyak 20 butir soal (soal pretes, postes siklus I dan Siklus II sama) nomor soal instrumen atau butir soal telah berubah saat digunakan peneliti dalam penelitiannya.

\section{Uji Reliabilitas Instrumen}

Realibilitas merupakan ukuran yang menyatakan tingkat keajengan atau kekonsistenan suatu soal tes. Bila suatu alat pengukur dipakai dua kali untuk mengukur 
segala yang sama dan hasli pengukur diperoleh relatif koefisien, maka alat pengukuran tersebut dikatakan reliable untuk menguji reliabilitas tes penelitian digunakan rumus KR-20(Jihad dan Haris, 2012: 180), sebagai berikut:

$r_{11}=\left[\frac{n}{n-1}\right]\left[1-\frac{\sum s_{i}^{2}}{s_{t}^{2}}\right]$

Keterangan :

$r_{11}=$ reliabilitas tes

n = banyaknya butir soal

$\sum s_{i}^{2} \quad=$ jumlah varians skor tiap item

$s_{t}^{2} \quad=$ varians skor total

Koefisien reliabelitas yang dihasilkan data dapat diinterprestasikan dengan pedoman kriteria (Jihad dan Haris (2013:181) seperti tabel dibawah ini.

Tabel 3.6 Makna Koefisien Korelasi Product Moment

\begin{tabular}{|c|c|c|}
\hline No & Angka Korelasi & Makna \\
\hline 1 & $0,800-1,000$ & Sangat Tinggi \\
\hline 2 & $0,600-0,800$ & Tinggi \\
\hline 3 & $0,400-0,600$ & Cukup \\
\hline 4 & $0,200-0,400$ & Rendah \\
\hline 5 & $0,000-0,200$ & Sangat Rendah \\
\hline
\end{tabular}

\section{Metode Analisis Data}

Analisis data yang dilakukan dengan tujuan untuk mengolah data hasil penelitian berupa data kasar menjadi data yang lebih mudah dibaca dan diinterprestasikan. Sanjaya (2010:106) menyatakan, "bahwa menganalisis data adalah suatu proses mengolah dan menginterprestasi data dengan tujuan untuk mendukung berbagai informasi sesuai dengan fungsinya hingga memiliki makna dan arti yang jelas sesuai dengan tunjuan penelitian". Sementara Sukardi (2013:79) menyatakan, "Analisis data penelitian tindakan kelas pada prinsipnya dilakukan secara berlanjut (continue) sejak peneliti terjun ke lapangan, bertemu dengan guru dan siswa di kelas.Analisis data penelitian tindakan kelas pada dasarnya berorientsi analisis deskripsi yang memiliki enam kegiatan penting yang menghimpun data, verifikasi data, dan melakukan interprestasi untuk membuat kesimpulan".

Dalam menganalisis data yang diperoleh dari instrumen penelitian yaitu tes, digunakan rumus sebagai berikut.

\section{Ketuntasan Hasil Belajar Siswa}

\section{a. Ketuntasan Hasil Belajar Individu}

Untuk menghitung ketuntasan hasil belajar individu dapat dihitung dengan menggunakan rumus sebagai berikut:

$K B=\frac{T}{T t} X 100 \%$

Keterangan :

$\mathrm{KB}=$ Ketuntasan belajar

$\mathrm{T}=$ Jumlah skor yang diperoleh siswa

$\mathrm{Tt}=$ Jumlah skor total

Hasil penghitungan disesuaikan dengan kriteria ketuntasan belajar siswa yang dikelompokkan ke dalam dua kategori tuntas dan tidak tuntas. Dengan kriteria sebagai berikut:

Tabel 3.5 Kriteria Ketuntasan Hasil Belajar Siswa

\begin{tabular}{l|l} 
Kriteri Ketuntasan & Kualifikasi
\end{tabular}

Volume: 1 No. 1 Juli 2018

JURNAL ILMIAH AQUINAS TERBIT JULI DAN JANUARI SETIAP TAHUNNYA 


\begin{tabular}{|c|c|}
\hline$>65$ & Tuntas \\
\hline$<65$ & Tidak tuntas \\
\hline
\end{tabular}

\section{b. Ketuntasan Hasil Belajar Klasikal}

Trianto (2011:241) menyatakan."Suatu kelas dikatakan tuntas belajarnya (ketuntasan klasikal) jika dalam kelas tersebut terdapat $\geq 85 \%$ siswa yang telah tuntas belajarnya".Untuk menghitung ketuntasan hasil belajar secara klasikal dapat dihitung dengan menggunakan rumus sebagai berikut:

$\mathrm{P}=\frac{\sum \text { siswayangtuntasbelajar }}{\sum \text { siswa }} X 100 \%$ (Aqib dkk, 2016:41)

Keterangan :

$\mathrm{P}=$ Presentase ketuntasan belajar

Tabel 3.6 Kriteria Tingkat Keberhasilan Belajar Siswa dalam \%

\begin{tabular}{|c|c|}
\hline Tingkat Keberhasilan (\%) & Penjelasan \\
\hline$>80 \%$ & Sangat Tinggi \\
\hline $60-76 \%$ & Tinggi \\
\hline $40-59 \%$ & Sedang \\
\hline $20-39 \%$ & Rendah \\
\hline$<20 \%$ & Sangat Rendah \\
\hline
\end{tabular}

Hasil analisis digunakan sebagai bahan refleksi untuk melakukan perencanaan lanjut dalam siklus berikutnya.Hasil analisis juga dijadikan sebagai bahan refleksi dalam memperbaiki rancangan pembelajaran.

\section{c. Rata-rata hasil belajar siswa}

Penelitian melakukan penjumlahan nilai yang diproleh siswa, yang selanjutnya dibagi dengan jumlah siswa yang ada di kelas tersebut sehingga diperoleh rata-rata hasil belajar siswa dapat dirumuskan :

$X=\frac{\sum \mathrm{X}}{\sum \mathrm{N}}$ (Aqib dkk, 2016:40)

Keterangan: $X \quad$ : Nilai rata-rata

$\sum \mathrm{X} \quad$ : Jumlah semua nilai siswa

$\sum \mathrm{N} \quad$ : Jumlah siswa

\section{Hasil Pelaksanaan Pembelajaran}

Pelaksanaan pembelajaran meliputi aktivitas guru dan aktivitas siswa, untuk menghitung nilai pelaksanaan pembelajaran pada aktivitas guru dan aktivitas siswa sebagai berikut:

\section{a. Pelaksanaan Pembelajaran Aktivitas Guru}

Untuk menghitung nilai pelaksanaan pembelajaran pada aktivitas guru, dapatdihitung dengan menggunakan rumus sebgai berikut:

$$
\text { Nilai }=\frac{\text { Jumla } h \text { hasil observasi }}{\text { Jumla } h \text { butir pengamatan }} \times 100 \% \ldots \ldots \ldots \ldots \ldots \ldots \ldots \ldots \ldots \ldots . \ldots . \ldots \ldots \text { (Sahertien. 2010:61) }
$$

Hasil penilaian pelaksanaan aktivitas guru dapat digunakan kriteria Sahertien (2010:61) sebagai berikut :

Tabel 3.7 Kriteria Penilaian dalam Pelaksanaan Pembelajaran Aktivitas Guru

\begin{tabular}{|c|c|}
\hline Kriteria Penilaian & Keterangan \\
\hline $\mathrm{A}=81-100 \%$ & Baik sekali \\
\hline $\mathrm{B}=61-80 \%$ & Baik \\
\hline $\mathrm{C}=41-60 \%$ & Cukup \\
\hline
\end{tabular}

Volume: 1 No. 1 Juli 2018 


\begin{tabular}{|c|c|}
\hline $\mathrm{D}=21-40 \%$ & Kurang \\
\hline $\mathrm{E}=0-20 \%$ & Sangat kurang \\
\hline
\end{tabular}

\section{b. Pelaksanaan Pembelajaran Aktivitas Siswa}

Untuk menghitung nilai pelaksanaan pembelajaran aktivitas siswa, dapat dihitung dengan menggunakan rumussebagai berikut:

Nilai Siswa $=\frac{\text { skorperole han }}{\text { skorMaksimum }} X 100 \ldots \ldots \ldots \ldots \ldots \ldots \ldots \ldots \ldots . .($ Jihad dan Haris, 2013:130)

Hasil penilaian pelaksanaan pembelajaran aktivitas siswa dapat digunakan kriteria Asep Jihad dan Haris (2013:131) sebagai berikut:

Tabel 3.8 Kriteria Penilaian dalam Pelaksanaan PembelajaranAktivitas Siswa

\begin{tabular}{|c|c|}
\hline Nilai & Kriteria \\
\hline $\mathrm{A}=90-100$ & Sangat baik \\
\hline $\mathrm{B}=70-89$ & Baik \\
\hline $\mathrm{C}=50-69$ & Cukup \\
\hline $\mathrm{D}=30-49$ & Kurang \\
\hline $\mathrm{E}=10-29$ & Sangat kurang \\
\hline
\end{tabular}

\section{Indikator Keberhasilan Penelitian}

Tampubolon (2014:35), bahwa "Penelitian tindakan kelas diasumsikan berhasil bila dilakukan tindakan perbaikan kualitas pembelajaran, maka akan berdampak terhadap perbaikan perilaku siswa dan hasil belajar. Menurut urutan indikator secara logika disusun menjadi:

1. Indikator keberhasilan kualitas proses pembelajaran minimal "baik" (indikator ini untuk tujuan umum dari penelitian).

2. Indikator keberhasilan hasil belajar secara klasikal $75 \%$ dari jumlah siswa yang mencapai KKM yang ditetapkan".

Catatan: Indikator 1 dan 2 menggunakan table konversi nilai (tabel 3.6)

Tabel 3.9 Indikator Keberhasilan Penelitian

\begin{tabular}{|c|c|c|}
\hline Interval Nilai & Kategori & Makna \\
\hline $81-100$ & A & Sangat baik \\
\hline $61-80$ & B & Baik \\
\hline $41-60$ & C & Cukup baik \\
\hline $21-40$ & D & Kurang baik \\
\hline $0-20$ & E & Jelek/Sangat tidak baik \\
\hline
\end{tabular}

\section{Desain Penelitian}

Sesuai dengan jenis penelitian ini yaitu penelitian Tindakan Kelas maka penelitian ini menggunakan desain yang dikemukakan oleh Suharsimi Arikunto, dkk (2015:42), dengan siklus terdiri dari 4 komponen yaitu: 1) Perencanaan, 2) Pelaksanaan, 3) Pengamatan dan 4) Refleksi.

\section{HASIL PENELITIAN DAN PEMBAHASAN}

Penelitian yang dilakukan oleh peneliti adalah penelitian tindakan kelas yang dilakukan dalam 2 siklus. Siklus yang dilaksana kan ini terdiri dari siklus I dan siklus II. Setiap siklus terdiri dari beberapa tahapan, yaitu tahap perencanaan, tahap tindakan, observasi, dan refleksi.Pada siklus II tahap-tahap yang dilakukan merupakan perbaikan dari siklus sebelumnya. 
Hasil yang diperoleh pada penelitian ini terdiri dari data tes yang berupa nilai hasil belajar Ilmu Pengetahuan Sosial (IPS) dan data non tes yang terdiri dari hasil observasi menggunkan lembar aktivitas guru dan siswa.Hasil dari kedua penelitain pada kedua siklus tersebut digunakan untuk mengetahui peningkatan hasil belajar Ilmu Pengetahuan Sosial (IPS) dengan menggunakan model kooperatif tipe Number Head Together(NHT) yang diperoleh siswa kelas III-B SD Negeri 064024 Medan Selayang.

Pada perolehan niali rata-rata hasil belajar Ilmu Pengetahuan sosial kelas III-B SD Negeri 064024 Medan Selayang pada kondisi awal atau pra siklus dilakukan pre tes adalah 57,02. Selanjutnya diberikan tindakan berupa penerapan model pembelajaran kooperatif tipe Number Head Together. Pada siklus I rata-rata hasil belajar ilmu pengetahuan sosial siswa kelas III-B SD Negeri 064024 Medan Selayang meningkat 3,06 dari 57,02 menjadi 60,08

Selain itu, tingkat ketuntasan siswa juga mengalami peningkatan dari kondisi awal siswa yang mengalami tuntas belajar sama dengan atau di atas nilai KKM sebanyak 8 siswa atau 32,00\% pada siklus I setelah diberikan tindkan dengan menggunakan model pembelajaran kooperatife tipe Number Head Together (NHT) jumlah ketuntasan siswa meningkat menjadi 10 siswa atau 40,00\%. Sesuai dengan kriteria keberhasilan ketuntasan siswa yang ditetapkan peneliti sebesar $75 \%$ maka siklus I belum memenuhi kriteria keberhasilan yang diharapkan. Maka dilanjutkan pada siklus II dengan tindakan yang sama yaitu penerapan model pembelajaran kooperatif tipe Number Head Together (NHT) pada pembelajaran Ilmu Pengetahuan Sosial (IPS).

Pada siklus II ini, rata-rata hasil belajar Ilmu Pengetahun Sosial (IPS) yang diperoleh siswa kelas III-B SD Negeri 064024 Medan Selayang adalah 77,06. Jadi dalam siklus II, terjadi peningkatan hasil belajar sebesar 16,98 dan mengalami peningkatan jumlah ketuntasan siswa menjadi 22 siswa atau 88,00\%. Dengan demikian, ternyata model Number Head Together (NHT) dapat meningkatkan hasil belajar Ilmu Pengetahuan Sosial (IPS) pada siswa kelas III SD Negeri 064024 Medan Selayang, itu terlihat dari hasil yang diperoleh dari pra tindakan sampai dengan siklus II yang selalu mengalami peningkatan.

\section{PENUTUP Simpulan}

Berdasarkan hasil penelitian mengenai peningkatan hasil belajar siswa kelas III pada mata pelajaran Ilmu Pengetahuan Sosial (IPS) SD Negeri 064024 Medan Selayang melalui model pembelajaran kooperatif tipe Number Head Together (NHT) dapat disimpulkan bahwa:

1. Hasil belajar siswa dalam pembelajaran Ilmu Pengetahuan Sosial (IPS) materi lingkungan alam dan buatan dengan menggunakan model pembelajaran kooperatif tipe Number Head Together (NHT) terjadi pengingkatan. Hal ini dapat dilihat dari presentase ketuntasan belajar klasikal pada pre tes sebesar 32,00\%, siklus I sebesar $40,00 \%$, dan pada siklus II sebesar $88,00 \%$ sehingga terjadi peningkatan.

2. Aktivitas Guru dalam pelaksanaan pembelajaran dengan menggunakan model pembelajaran kooperatif tipeNumber Head Together (NHT) pada mata pelajaran IPS materi lingkungan alam dan buatan terjadi peningkatan. Hal ini dapat dilihat berdasarkan rata-rata presentasi skor aktivitas guru secara umum siklus I sebesar $68 \%$ masi dalam kategori cukup, pada siklus II sebesar $84 \%$ sudah dalam kategori sangat baik dan telah memenuhi indikator keberhasilan. 
3. Aktivitas siswa dalam pelaksanaan pembelajaran dengan menggunakan model pembelajaran kooperatif tipeNumber Head Together (NHT) pada mata pelajaran IPS materi lingkungan alam dan buatan terjadi peningkatan. Hal ini dapat dilihat berdasarkan rata-rata presentasi skor aktivitas siswa secara umum siklus I sebesar 52\% masih dalam kategori cukup, pada siklus II sebesar $80 \%$ sudah dalam Implikasi kategori baik dan telah memenuhi indikator keberhasilan.

Penelitian ini menunjukkan bahwa adanya peningkatan hasil belajar siswa pada mata pelajaran IPA pada materi lingkungan alam dan buatan menggunkan model pembelajaraan kooperatif tipeNumber Head Together (NHT) di laksanakan pada kelas III-B SD Negeri 064024 Medan Selayang. Dalam penelitian ini juga memberikan bukti bahwa menggunakan model pembelajaraan kooperatif tipe Number Head Together (NHT) menuntut siswa aktif dalam pembelajaran, hal ini dikarenakan siswa yang lebih aktif dalam pembelajaran dan berdiskusi sesama temannya dan mengajari temannya yang kurang mampu. Dalam proses pelaksanaan belajar mengajar guru diharapkan dapat menerapkan model pembelajaran kooperatif tipe Number Head Together yang disesuaikan dengan materi pelajaran agar tujuan pembelajaran dapat tercapai. Penerapan model pembelajaran kooperatif tipe Number Head Together berdampak terhadap peningkatan hasil belajar siswa, dimana hasil belajar IPS masih tergolong rendah. Oleh karena itu, dalam upaya meningkatan hasil belajar perlu menggunakan model yang menerik perhatian siswa agar lebih rajin dan semangat dalam belajar, salah satunya adalah dengan menggunakan model pembelajaran kooperatif tipe Number Head Together.

\section{Keterbatasan Penelitian}

Dalam penelitian ini terdapat keterbatasan-keterbatasan yang diharapkan akan membuka kesempatan bagi peneliti lainnya untuk melakukan penelitian sejenis yang akan berguna bagi perluasan wawasan keilmuan. Diantara keterbatasan-keterbatasan itu sebagai berikut:

1. Penelitian ini hanya terbatas pada satu model pembelajaran kooperatif tipe Number Head Together untuk meningkatkan hasil belajar siswa, seperti: sikap terhadap guru, teman, dan sebagainya. Dengan demikian kondisi-kondisi itu bisa saja ikut dalam mempengaruhi hasil belajar siswa pada pembelajaran.

2. Proses diskusi yang kurang terarah menyebabkan banyak waktu yang terbuang dengan sia-sia.

3. Kurangnya waktu yang dibutuhkan dalam penerapan model Number Head Together sehingga proses melebihi waktu jam pelajaran.

\section{Saran}

Berdasarkan simpulan dan implikasi di atas, maka dapat diberikan beberapa saran sebagai berikut:

1. Kepada guru kelas, agar mencoba menerapkan model pembelajaran kooperatif tipe Number Head Together (NHT) sebagai alternatif untuk meningkatkan hasil belajar siswa.

2. Kepada pihak sekolah, agar mencoba mengembangkan model pembelajaran kooperatif tipe Number Head Together (NHT) sebagai upaya pengembangan sekolah, utamanya untuk peningkatan kualitas proses pembelajaran di sekolah.

3. Kepada peneliti lain, agar menjadikan hasil penelitian ini sebagai bahan referensi untuk melakukan penelitian lebih lanjut mengenai pelaksanaan pembelajaran menggunakan model pembelajaran kooperatif tipe Number Head Together (NHT), sehingga diperoleh hasil penelitian yang lebih maksimal lagi. 


\section{DAFTAR PUSTAKA}

Aqib, Zainal, dkk. 2011. PenelitianTindakanKelasuntuk SD, SLB, dan TK. Bandung: CV YramaWidya.

Arikunto, Suharsimi, dkk. 2015. Penelitian Tindakan Kelas. Jakarta: PT Bumi Aksara. Asep Jihad dan Abdul Haris. 2013. Evaluasi Pembelajaran. Yogyakarta: Multi Pressindo.

Dimayanti dan Mudjiono. 2012. Belajar\&Pembelajaran. Jakarta: PT AsdiMahasatya. Hamalik, Oemar. 2014. Kurikulum dan Pembelajaran. Jakarta: PT Bumi Aksara. Istarani dan Intan Pulungan. 2016. Ensiklopedia Pendidikan. Medan: LARISPA. Istarani. 2014. 58 Model Pembelajaran Inovatif. Medan: Media Persada.

Mardiati. 2015. Penerapan Model Number Heads Together dengan Media GambaruntukMeningkatkanKualitasPembelajaran IPS padaSiswaKelas III SDN Karangayu 03 Kota Semarang. TahunAjaran 2014/2015. Skripsipdf.UniversitasNegeri Semarang.

Muhammedi, Elfidayati. 2017. Psikologi Belajar. Medan: LARISPA INDONESIA. Purwanto. 2014. Evaluasi Hasil Belajar. Yogyakarta: Pustaka Belajar.

Rusman. 2011. Model-Model PembelajaranMengembangkanProfesionalisme Guru. Jakarta: PT Raja Grafindo Persada.

Sahertian, A Piet. 2010. Konsep Dasardan Teknik Supervise Pendidikan dalam RangkaPengembangan Sumber Daya Manusia. Jakarta: PT Asdi Mahasatya. .2010. Konsep dan Makna Pembelajaran. Bandung: Alfabeta.

Sanjaya, Wina. 2011. Strategi PembelajaranBerorientasiStandar Proses Pendidikan. Jakarta: Kencana Prenada Media.

Sembiring, BinaKurnia. 2016. MeningkatkanHasilBelajarMatematikaMelalui Model PembelajaranKooperatifTipe Number Head Together PadaSiswaKelas V SD Negeri 104218 SidomulyoKecamatanBiru-BiruTahunPelajaran 2015/2016. Skripsi.Universitas Quality.

Shoimin, Aris. 2014. 68 Model Pembelajaran Inovatif dalam Kurikumum 2013. Yogyakarta: AR-RUZZ-MEDIA.

Slameto. 2013. Belajar dan Faktor-Faktor yang Mempengaruhi. Jakarta: PT. Rineka Cipta.

Sudjana, Nana. 2012. Penilaian Hasil Proses Belajar Mengajar. Bandung: PT Remaja Rosdakarya.

Sugiyono. 2012. Metode Penelitian Pendidikan. Bandung: Wacana Prima.

Suprijono, Agus. 2010. Cooperative LearningTeori\&AplikasiPaikem. Yogyakarta: Pustakabelajar.

Susanto, Ahmad. 2016. Teori Belajar dan Pembelajaran. Yogyakarta: Multi Presindo. Susanto,Ahmad. 2014. Pengembangan Pembelajaran IPS. Jakarta: PRENADAMEDIA GROUP.

Tampubolon, Saur. 2014. Penelitian Tindakan Kelas. Jakarta: Erlangga.

Trianti. 2010. Mendisain Pembelajaran Inovatif-Progresif. Jakarta: Kenacana. 